\title{
Xeriscaping Feasibility as an Urban Adaptation Method for Global Warming: A Case Study from Turkey
}

\author{
Nefise Çetin ${ }^{1}$, Sibel Mansuroğlu ${ }^{1}$, Ayşe Kalaycı Önaç²* \\ ${ }^{1}$ Akdeniz University, Faculty of Architecture, Department of Landscape Architecture \\ ${ }^{2}$ Kastamonu University, Faculty of Engineering and Architecture, Department of Landscape Architecture
}

Received: 31 May 2017

Accepted: 26 August 2017

\begin{abstract}
Green spaces are of great importance in the image of a city. But water resources are gradually decreasing due to the increase in world population, climate change related to global warming, unconscious consumption of water resources, and pollution. In landscaping, incorrect plant choices and the use of grass in expansive areas may also increase pressure on limited water resources. In summer, scenes of yellow, dry, and even dead landscaping designs are increasingly common where correct landscaping designs are not employed. This study consists of data collected to obtain a better understanding of the study area, Antalya/Konyaalti, regarding its natural features and xeriscape, and a cost estimate of construction and maintenance of a proposed design project. It was prepared taking into consideration the existing landscape design and the xeriscape principles of the pilot park. Results were compared in terms of economic and environmental contributions. From the perspective of the literature review to date, this study is one of the first aimed at determining the construction and maintenance costs of xeriscape practices to be conducted on a park scale in the context of public spaces nationally and internationally. The potential benefits of the xeriscape in Mediterranean conditions have been quantitatively and qualitatively demonstrated. Recommendations are made for the redesign of the existing park based on xeriscaping, which could save $57.24 \%$ of the construction costs and $54.91 \%$ in annual maintenance costs. We conclude that xeriscaping can contribute to ecology by providing water savings, reducing chemical use, and preventing soil pollution.
\end{abstract}

Keywords: xeriscape, landscape design, feasibility analysis

\section{Introduction}

The development of the art of landscape gardening, dating back to 4000 B.C., shows that historically gardens were made for personal taste and use rather than for public

*e-mail: ayseklyc@gmail.com

interest or the care of resources. Over time, along with the emergence of public recreational spaces, it has become clear that existing natural resources should also be protected and managed [1]. Although more than $70 \%$ of the Earth's surface is covered in water, usable freshwater is extremely limited, comprising just $2.5 \%$ of the total. Most of this freshwater exists either underground in subterranean aquifers or locked up in polar ice caps and glaciers. Only $1.2 \%$ is available as surface freshwater 
contained in rivers, lakes, streams, and the atmosphere [2].

Choiński et al. [3] emphasize that most water resources are consumed by anthropogenic factors, and this impacts climate conditions. Among the greatest challenges for architects and planners today are reducing operating costs and creating more livable spaces in urban areas through sustainable designs. Efficient water management that simulates the natural hydrological cycle is one of the key elements of sustainable design [4-5].

Some researchers, such as Knox [6], Aklanoğlu [7], Barış [8], and Ertop [9] have pointed out that water resources are gradually decreasing and so water-saving landscape designs should be preferred to classical landscape concepts. Xeriscaping is a holistic approach that uses planning, designing, and selecting appropriate indigenous plant species, water-efficient irrigation techniques, and other practices to make landscaping more sustainable [10]. It has been suggested by many researchers also for capturing a large amount of $\mathrm{CO}_{2}$ with few irrigation requirements [11-12]. There are a number of strategies, tools, alternatives, and management practices that can significantly reduce or conserve water use in urban landscapes. Use of water-conserving landscape plants and designs suitable for each soil type and climate have been predominantly promoted as foundational components of water conservation [13-15]. These approaches make possible eco-friendly landscaping, which reduces construction and maintenance costs of green areas, favoring both nature and the economy [16]. The U.S. Environmental Protection Agency [17] describes the specific benefits of xeriscaping as:

"Reduced water use, decreased energy use (less pumping and treatment required), reduced heating and cooling costs because of carefully placed trees, decreased stormwater and irrigation runoff, fewer yard wastes, increased habitat for plants and animals, and lower labor and maintenance costs."

The principles of xeriscaping are listed as [18-19]:

- Design the landscape based on a whole site analysis.

- Limit turf areas and use grasses appropriate for the region.

- Amend poor soils to increase water absorption and retention.

- Mulch plantings to reduce evapotranspiration.

- Select plant material that is naturally adaptable to site conditions.

- Use water-efficient irrigation systems.

- Maintain landscapes appropriately.

A number of comparative studies have examined the outcomes of xeriscaping versus traditional methods. Wade and Weatherly [20] designed two imaginary residential gardens - one based on xeriscaping and one on classical landscaping - and then calculated and compared the annual costs of water consumption, maintenance, wastewater, and water bills. Also in the United States, Santo [21] comparatively examined xeriscaping principles and established practices in the region around Atlanta, Georgia (U.S.A.) and other states, and calculated the percentage differential in water savings. Using computer models, Baykan and Birişçi [22] and Şahin [23] selected and designed areas according to xeriscaping methods, emphasizing points that should be taken into consideration: plant selection, massing of plants needing similar growth conditions, mulching, etc. Wade et al. [24] and Welsh [25] examined housing gardens before and after implementing xeriscape practices for plants and irrigation. Researchers such as Taner [26], Çakıroğlu [27], Şahin [23], Keane [28], Welsh [25], and Wade et al. [24] described the xerotolerant (drought tolerant) plant species that can be used in xeriscaping.

A landscape design that is carried out in order to use less water should include $[5,29]$ :

- Land grading.

- Soil analysis and amendments.

- Appropriate plant selection and proper use of turf.

- Efficient irrigation techniques considering the local climate.

- Use of mulches.

- Suitable fertilizers and pesticides.

- Regular maintenance of planting and irrigation systems.

The objectives of this study, which was conducted in the province of Konyaalt1, Antalya (Turkey), are:

- To demonstrate the feasibility of xeriscaping in Mediterranean conditions using both quantitative and qualitative values.

- To draw the attention of institutions and organizations that are interested in the quantitative benefits of the xeriscape design.

- To increase the efficiency of green areas, especially in summer, and to enable sustainable landscaping designs.

- To contribute to the spread of xeriscaping practices.

- To use natural resources - especially water economically.

- To obtain outcomes that will contribute to the environment and the economy.

In accordance with the above-mentioned goals, information about xeriscaping was obtained and data was collected on the natural features of the Konyaalt District, and then the cost of the proposed design projects (construction and maintenance) were calculated based on comparing an existing public space selected from the Konyaalt1 area and a proposed xeriscape plan. The resulting data were analyzed in terms of their economic and environmental contributions. Some suggestions are made for Mediterranean conditions on the basis of the Konyaaltı case, and then the feasibility of the Xeriscape is discussed for Mediterranean conditions in general.

\section{Material and Methods}

\section{Material}

The Konyaaltı District is one of the five central districts of Antalya - the tourism capital in southern 

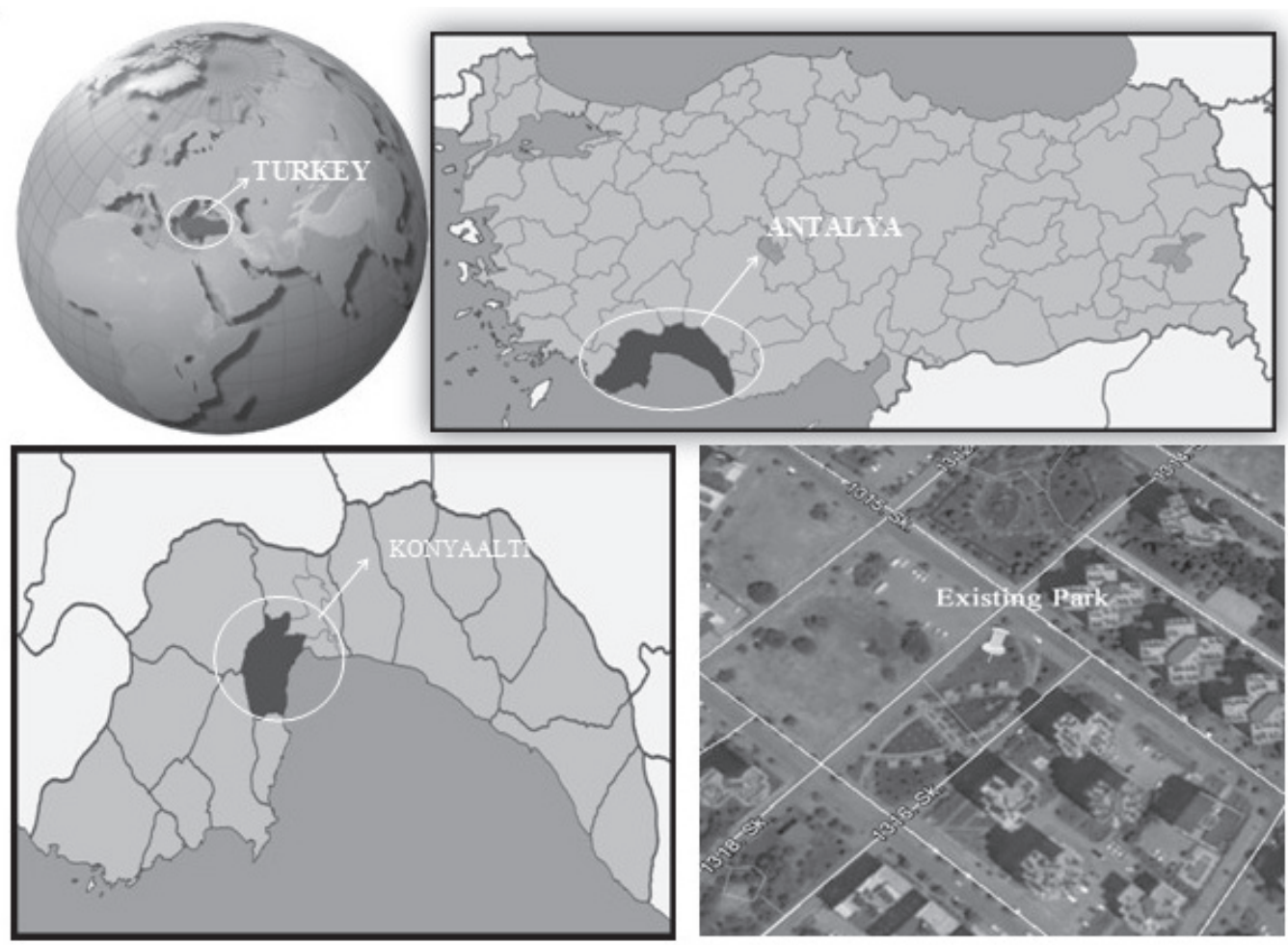

Fig. 1. Location of study area.

Turkey known for its world-famous coast - and from among the public spaces in that region that focus on the park in its Siteler Neighborhood (Fig. 1).

Konyaalt1, with a surface area of $562.4 \mathrm{~km}^{2}$, has a population of 145.648 according to 2014 census figures [30-31] and features 127 parks, two squares, five outdoor sports venues, and other green areas within its municipal borders [32]. The geological structure of the research area was obtained from the 1/100,000-scale geological map prepared by the General Directorate of Mineral Research and Exploration [33]. The soil properties of the study area were determined using the map prepared by the General Directorate of Rural Services [34], and its report, Antalya Land Assets [35]. In order to determine the climatic characteristics, data for 2007-14, prepared by the Fourth Regional Directorate of MGM (Directorate General of Meteorology) [36], have been utilized and research data from "Antalya Region" climate station No. 17302, which is located $47 \mathrm{~m}$ above sea level and at a latitude of 36 and longitude of 30 . The overall cost of developing the current park was calculated based on data obtained from Konyaaltı Municipality [37]. The annual maintenance costs of the existing and proposed projects have been calculated by obtaining a price quote from three landscaping companies: CRN Peyzaj, Mavi Peyzaj, and Tetikler Peyzaj. The annual maintenance schedule of the existing and proposed landscape design projects was determined by consulting specialists of these companies and also Seki Peyzaj, Antalya Forest Nursery, Pey Art Peyzaj, and Damla Peyzaj companies, who submitted quotes for the plantation supply of the proposed project.

\section{Method}

Research was carried out in four stages in the field and in the office (Fig. 2).

First, a literature review was conducted about the xeriscape and data were collected on the natural structural properties (geology, morphology, soil, hydrology, and climate) of the Konyaaltı District. Then a small park in the Konyaaltı area was re-envisioned based on xeriscaping principles, and the costs of

GATHERING RESEARCH SUBJECT AND FIELD-RELATED DATA

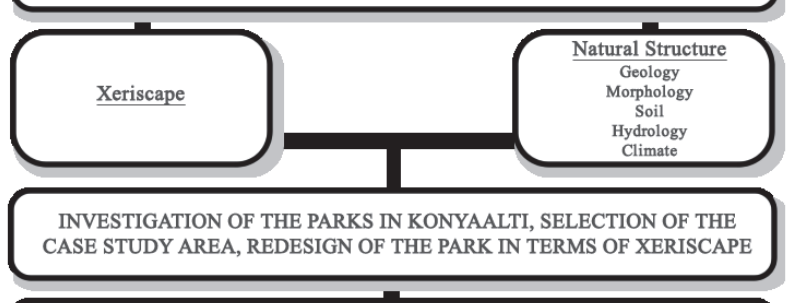

CALCULATION OF THE COSTS OF SAMPLE PARK IN TERMS OF XERISCAPE AND EXISTING CONDITIONS

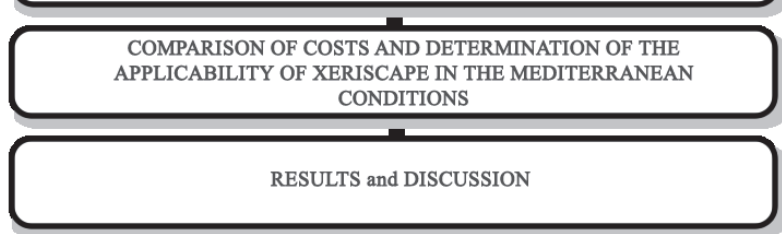

Fig. 2. Research method flow diagram. 
construction and maintenance (irrigation, fertilization, mulching, pruning, mowing, spraying) of the existing and proposed projects were calculated. Comparisons were made based on these calculations. Finally, the study demonstrated qualitatively and quantitatively the benefits of xeriscaping in Mediterranean conditions. Suggestions were made on the basis of these findings. Although the structural arrangement of the park, which is the study area, remained untouched, we conceived a new design in accordance with xeriscaping principles based on the natural properties of the area. In selecting plants, those most suitable for the park were chosen from a chart detailed in a study conducted by Çetin, which elaborates upon various studies on Mediterranean conditions and forest nurseries [38]. The general cost of the existing park design was determined from data obtained from Konyaaltı Municipality [37] (Fig. 3).

Following the method employed by the municipality in determining cost estimates, annual maintenance outlays for the existing and proposed projects were calculated by averaging the proposal prices of the three firms. For the proposed project, fair market prices were calculated by averaging those for plant and turf materials and the mulching materials for additional landscaping, from the same firms. Only these three companies could offer bids,

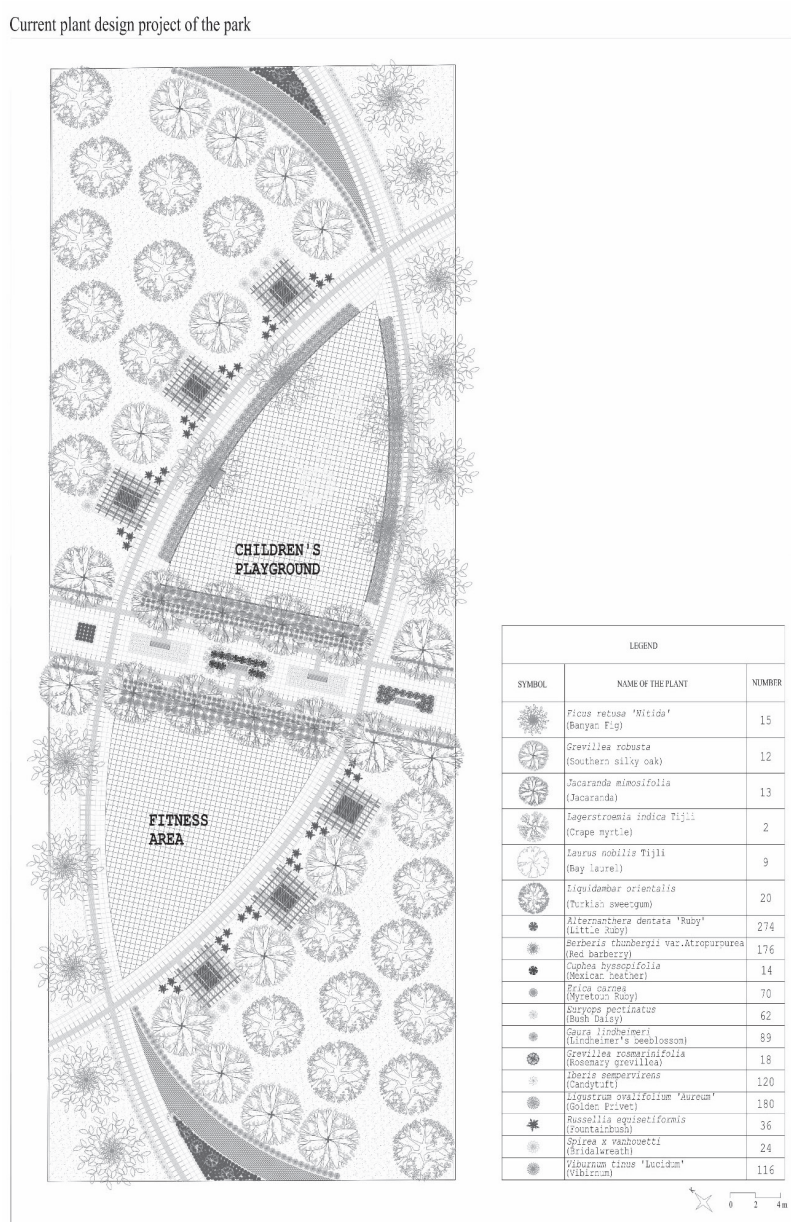

Fig. 3. Study area: existing park. because appropriate plants, or those of desired size and specifications, were not available elsewhere.

Microsoft Excel 2010 software was used for calculations. To make prices more comparable, particular attention was paid to plant size and pot size in the proposed project in order that they match those of the existing project to avoid discrepancies. As Autocad software was used for imaging the existing project, it was used also for the proposed project's illustrations in order to equalize the designs aesthetically.

\section{Results and Discussion}

\section{Results}

\section{Xeriscape}

"Xeriscape" is a modern compound word that emerged in the early 1980s in the city of Denver, Colorado, U.S.A. $[25,39]$. It combines "xeros," which means arid in Greek, and "landscape," which includes "terrain" among its connotations in English.

Xeriscaping offers ecological, economic, and aesthetic benefits. Ecological advantages include ensuring water savings, contributing to water resources, creating habitats for plants and wildlife, protecting biodiversity, improving soil, inhibiting erosion, reducing chemical use, and preventing groundwater pollution. Reducing maintenance and labor costs; saving energy, time, and effort; and decreasing water bills are among its economic advantages. Improving the visual quality of the environment along with diversity in design are among its aesthetic rewards [9, 25-26, 40-41].

\section{Natural (Structural) Properties}

In landscaping practices, in order to achieve sustainable results it is necessary to know the components that comprise the natural structure of the area and to make vegetative and structural determinations based on this data. Those of the park under study were mapped and the results of the analysis summarized below.

The geological structure of Konyaaltı District includes various formations. Limestone comprises the largest part, with a percentage of $26.76 \%$ of the study area. Red Mediterranean soils (83.13\%), shallow soils $(0-20 \mathrm{~cm})(52.37 \%)$, Class VII soils $(48.82 \%)$, and a majority of lands with soil insufficiency and slope and erosion damage $(40.84 \%)$ are also noteworthy. Topographically, $46.59 \%$ of the expanse is steep (with $30 \%$ or more sloping land), while $21.02 \%$ of the terrain is flat (or almost flat: $0-2 \%$ ). The coastal terrain is nearly flat, while the sloping areas increase in the terrestrial zones. Therefore, land where there is not any dominant direction/ vector occupies the largest area with a percentage of 17.44\%. The streamlets of Boğaçayı, Arapsuyu, and Sarısu are the primary water sources [35]. 
According to Antalya Regional Station data, the average temperature is $19.9^{\circ} \mathrm{C}$, the average high temperature is $24.2^{\circ} \mathrm{C}$, and the average low temperature is $16.9^{\circ} \mathrm{C}$. The highest temperature was $43.8^{\circ} \mathrm{C}$ on the 24 July 2007, while the lowest temperature was $0.6^{\circ} \mathrm{C}$ on the 19 February 2008. The hottest months in Konyaalt1 are June, July, and August, while the coldest months are December, January, and February. Analyzing the hydrometric diagram drawn based on these data reveals that there is an arid period that lasts approximately five-and-a-half months from mid-April until the end of September.

\section{Designing the Proposed Plant Project Suitable for Xeriscaping}

The park was redesigned according to xeriscaping principles, but without any structural changes. At this stage, the natural structural properties of the area where the park is located (geology, morphology, soil, hydrology, climate) were taken into consideration. Plants were selected from a comprehensive list of two hundred prepared for this study based on literature. The selection process paid particular attention to species naturally resistant to drought; plant species appropriate

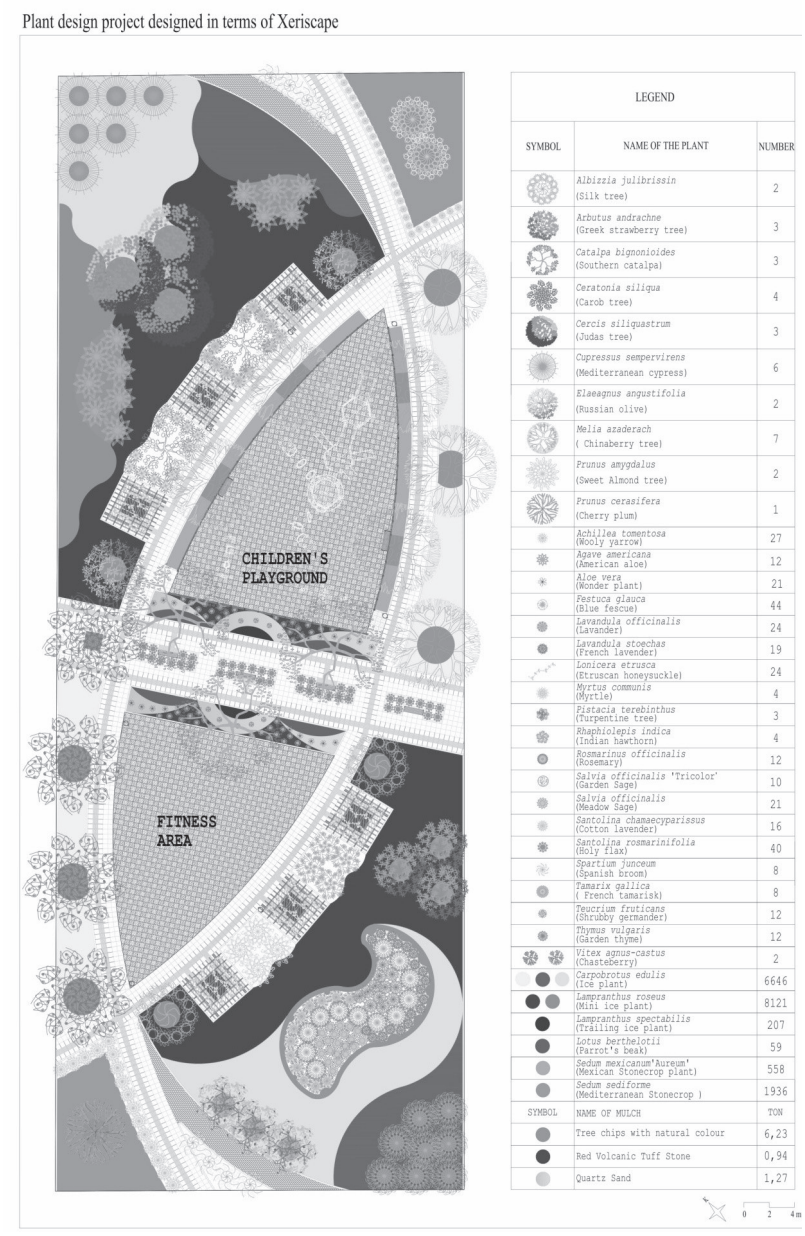

Fig. 4. Study area: proposed project. to designated locations, and the grouping of varieties with the same maintenance requirements. In addition, in areas unsuitable for functional use, ground cover plants which consume less water, require less maintenance, are more sustainable, and offer a more colorful and aesthetic appearance - were preferred to lawns. The plan calculated 15 succulent ground cover plants per square meter. Mulching was recommended for its many advantages for certain plant beds (tree, shrub, bush, perennial, and succulent plants), especially with respect to water savings (Fig. 4). In the case of irrigation, a water-saving drip system was recommended. In short, an effort was made toward an aesthetic design following xeriscaping principles in order to contribute to the environment and reduce both construction (start-up) and maintenance costs.

\section{Calculating Supply and Annual Maintenance Costs of Existing and Proposed Projects}

The existing project utilizes 71 trees-shrubs and 1,179 bush perennials. It features $1,477.28 \mathrm{~m} 2$ of lawn area employing $49.07 \mathrm{~m} 3$ of turf. The total cost for tree-shrubs was $€ 6,118.52$, for bush-perennials $€ 3,233.90$, and for the lawn $€ 400.93$. The total cost of the turf was $€ 1,126.59$. The estimated cost of the plant supply was $€ 10,879.94$ (Table 1).

The proposed project was designed based on the xeriscape to include 44 tree shrubs (€735,280), 312 bush perennials (€515.99), 17,527 ground-cover plants $(€ 2,500.23)$, and $49.07 \mathrm{~m}^{3}$ turf, for an estimated total cost of $€ 4,652.52$ (Table 2).

The annual maintenance procedures applied to both the existing and the proposed projects are shown in Table 3. The annual cost of the existing project is $€ 10,471.37$, while that of the proposed project is $€ 4,721.15$.

Unlike the existing project, the proposed project utilizes mulching materials (quartz sand, woodchip, volcanic tuff) in accordance with xeriscaping principles due to their numerous benefits - especially water savings. Therefore, an additional cost amounting to $€ 510.24$ arose in the structural application item of the budget (Table 4).

\section{Discussion}

Antalya has been experiencing an unusually long arid period of five and a half months, and it is projected that this arid period is likely to continue for the time being. Data indicate that there has been a decline in precipitation and an increase in temperature in recent years, i.e., drought has increased and the designs and practices that ensure water savings such as xeriscaping are needed.

Xeriscape landscaping practices, rather than using plants that require more care or that are non-indigenous, employ drought-tolerant species, decrease seasonal plant use, reduce lawn areas as much as possible or use drought tolerant grasses, and as ground cover turn to succulent species with low water consumption. 
Table 1. Current project plant supply summary [37].

\begin{tabular}{|c|c|c|c|c|c|c|}
\hline $\begin{array}{l}\text { Item } \\
\text { No. }\end{array}$ & Pose number & Explanation & Unit & $\begin{array}{c}\text { Total } \\
\text { amount }\end{array}$ & $\begin{array}{l}\text { Price } \\
(€)\end{array}$ & $\begin{array}{c}\text { Total price } \\
(€)\end{array}$ \\
\hline 1 & Market value & Ficus benjamin, $2 \mathrm{~m}$ of Tijli, CLT50, $14-16 \mathrm{~cm}, 300-350 \mathrm{~cm}$ & Number & 15 & 82.51 & $1,237.62$ \\
\hline 2 & Market value & Grevillea robusta, CLT50, $14-16 \mathrm{~cm}, 300-350 \mathrm{~cm}$ & Number & 12 & 76.77 & 921.22 \\
\hline 3 & Market value & Jacaranda mimosifolia, CLT50, $14-16 \mathrm{~cm}, 300-350 \mathrm{~cm}$ & Number & 13 & 83.23 & $1,081.93$ \\
\hline 4 & Market value & Lagerstromia indica Tijli, CLT50, $14-16 \mathrm{~cm}, 250-300 \mathrm{~cm}$ & Number & 2 & 99.73 & 199.45 \\
\hline 5 & Market value & Laurus nobilis Tijli, CLT50, $12-14 \mathrm{~cm}, 150-200 \mathrm{~cm}$ & Number & 9 & 112.64 & $1,013.78$ \\
\hline 6 & Market value & Liquidambar orientalis, CLT70, $16-18 \mathrm{~cm}, 400-450 \mathrm{~cm}$ & Number & 20 & 83.23 & $1,664.51$ \\
\hline 7 & Market value & $\begin{array}{l}\text { Spirea x vanhouetti, (min. } 50 \mathrm{~cm} \text { çap), CLT10, } 80-100 \mathrm{~cm} \text {, } \\
\text { fully textured }\end{array}$ & Number & 24 & 3.80 & 91.26 \\
\hline 8 & Market value & $\begin{array}{c}\text { Alternanthera dentata 'Ruby', CLT 3, 25-30 cm, fully } \\
\text { textured }\end{array}$ & Number & 274 & 1.29 & 353.85 \\
\hline 9 & Market value & $\begin{array}{l}\text { Berberis thunbergii var. Atropurpurea, CLT } 5,40-50 \mathrm{~cm} \text {, } \\
\text { fully textured }\end{array}$ & Number & 176 & 2.58 & 454.58 \\
\hline 10 & Market value & Cuphea hyssopifolia, CLT $7,50-70 \mathrm{~cm}$, fully textured & Number & 14 & 2.08 & 29.13 \\
\hline 11 & Market value & Erica carnea, CLT $4,30-35 \mathrm{~cm}$, fully textured & Number & 70 & 4.95 & 346.53 \\
\hline 12 & Market value & Europs pectinatus, CLT $4,40-45 \mathrm{~cm}$, fully textured & Number & 62 & 2.58 & 160.14 \\
\hline 13 & Market value & Gaura lindheimeri, CLT $5,45-50 \mathrm{~cm}$, fully textured & Number & 89 & 1.43 & 127.71 \\
\hline 14 & Market value & Grevillea rosmarinifolia, CLT $7,50-70 \mathrm{~cm}$, fully textured & Number & 18 & 7.53 & 135.60 \\
\hline 15 & Market value & Iberis sempervirens, CLT 3, $25-30 \mathrm{~cm}$, fully textured & Number & 120 & 3.09 & 370.21 \\
\hline 16 & Market value & $\begin{array}{l}\text { Ligustrum ovalifolium 'Aureum', CLT 9, 60-80 cm, fully } \\
\text { textured }\end{array}$ & Number & 180 & 2.22 & 400.34 \\
\hline 17 & Market value & Russelia equisetiformis, CLT 9, 60-80 cm, fully textured & Number & 36 & 2.51 & 90.40 \\
\hline 18 & Market value & Viburnum tinus 'Lucidum', CLT 7, 50-70 cm, fully textured & UNIT & 116 & 5.81 & 674.13 \\
\hline 19 & Market value & Lollium perenne $\left(35 \% 60\right.$ gr per $\left.\mathrm{m}^{2}\right)$ & KG & 31.02 & 3.52 & 109.05 \\
\hline 20 & Market value & Festuca rubra rubra $\left(35 \% 60\right.$ gr per $\left.\mathrm{m}^{2}\right)$ & KG & 31.02 & 3.44 & 106.83 \\
\hline 21 & Market value & Cynodon dactylon $\left(30 \% 60\right.$ gr per $\left.\mathrm{m}^{2}\right)$ & KG & 26.59 & 6.96 & 185.05 \\
\hline 22 & Market value & Peat (double harvested, sieved, disinfected) $(3 \mathrm{~cm})$ & $\mathrm{m}^{3}$ & 49.07 & 22.96 & $1,126.59$ \\
\hline \multicolumn{3}{|c|}{ Prepared according to 2013 market values } & \multicolumn{3}{|c|}{ TOTAL } & $10,879.94 €$ \\
\hline
\end{tabular}

Accordingly, this study generally used indigenous plants. Introduced species are comparatively expensive and require fertilization that can harm indigenous plants by transmitting new diseases and pests. The use of native species is of great importance in ensuring their long-term ecological survival and in reflecting regional identity and culture. Lending themselves to reduced start-up construction and maintenance costs, especially irrigation, natives have shown that it is possible to make designs that are as aesthetic as they are practical and sustainable.

The existing park uses a very limited number of species - all of them introduced. The proposed park aims to increase ecological richness by utilizing a wide variety of compatible plants. While the existing park employs some drought-tolerant plants, for xeriscaping their numbers are insufficient to reduce irrigation and other maintenance needs. Moreover, irrigation does not consist solely of water costs, but also includes those for system requirements for irrigation pipes, lines, etc. in significant amounts in a large-scale park [42].

This study shows: 1) that when comparing the construction outlays of the existing park to those of the proposed park based upon xeriscape principles, the proposed park would save €6,227.42 (57.24\%) and 2) in terms of annual maintenance, comparison with the existing park shows that the proposed park would save $€ 5,750.22$ (54.91\%). When calculated in Turkish lira, it was projected that a $46.23 \%$ savings would be achieved for construction and a $43.31 \%$ savings would be achieved for maintenance, taking into account that calculations made in euros were based on exchange rates during the period of this study. In the existing park, 51.38\% $\left(1,477.28 \mathrm{~m}^{2}\right)$ of the area is composed of lawns, which is the main reason for the higher maintenance cost. Lawn areas always need regular maintenance such as irrigation, fertilization, mowing, sowing, and spraying to maintain 
Table 2. Proposed project plant supply summary

\begin{tabular}{|c|c|c|c|c|c|c|}
\hline $\begin{array}{l}\text { Item } \\
\text { No. }\end{array}$ & Pose number & Explanation & Unit & Total & $\begin{array}{c}\text { Price } \\
(€)\end{array}$ & $\begin{array}{c}\text { Total price } \\
(€)\end{array}$ \\
\hline 1 & Market value & Albizzia julibrissin, CLT 50, $12-14 \mathrm{~cm}, 250-300 \mathrm{~cm}$ & Number & 2 & 19.63 & 39.26 \\
\hline 2 & Market value & Arbutus andrachne, CLT $35,10-12 \mathrm{~cm}, 150-200 \mathrm{~cm}$ & Number & 3 & 11.75 & 35.26 \\
\hline 3 & Market value & Catalpa bignonioides, CLT 50, $14-16 \mathrm{~cm}, 300-350 \mathrm{~cm}$ & Number & 3 & 16.32 & 48.96 \\
\hline 4 & Market value & Ceratonia siliqua, CLT $50,16-18 \mathrm{~cm}, 300-350 \mathrm{~cm}$ & Number & 4 & 18.72 & 74.86 \\
\hline 5 & Market value & Cercis siliquastrum, CLT $50,14-16 \mathrm{~cm}, 300-350 \mathrm{~cm}$ & Number & 3 & 34.35 & 103.05 \\
\hline 6 & Market value & Cupressus sempervirens, CLT 35, 175-200 cm & Number & 6 & 20.43 & 122.56 \\
\hline 7 & Market value & Eleagnus angustifolia, CLT $50,16-18 \mathrm{~cm}, 300-350 \mathrm{~cm}$ & Number & 2 & 23.05 & 46.10 \\
\hline 8 & Market value & Melia azaderach, CLT 50, $14-16 \mathrm{~cm}, 300-350 \mathrm{~cm}$ & Number & 7 & 24.31 & 170.15 \\
\hline 9 & Market value & Prunus amygdalus, CLT 50, $14-16 \mathrm{~cm}, 250-300 \mathrm{~cm}$ & Number & 2 & 12.78 & 25.56 \\
\hline 10 & Market value & Prunus cerasifera, CLT 50, $14-16 \mathrm{~cm}, 250-300 \mathrm{~cm}$ & Number & 1 & 20.43 & 20.43 \\
\hline 11 & Market value & Achillea tomentosa, CLT $2,20-25 \mathrm{~cm}$, fully textured & Number & 27 & 1.31 & 35.43 \\
\hline 12 & Market value & Agave americana, CLT $5,40-50 \mathrm{~cm}$, fully textured & Number & 12 & 4.22 & 50.67 \\
\hline 13 & Market value & Aloe vera, CLT $2,20-25 \mathrm{~cm}$, fully textured & Number & 21 & 1.83 & 38.34 \\
\hline 14 & Market value & Festuca glauca, CLT 2, 20-25 cm, fully textured & Number & 44 & 1.20 & 52.72 \\
\hline 15 & Market value & Lavandula officinalis, CLT $3,25-30 \mathrm{~cm}$, fully textured & Number & 24 & 1.31 & 31.50 \\
\hline 16 & Market value & Lavandula stoechas, CLT $3,25-30 \mathrm{~cm}$, fully textured & Number & 19 & 1.31 & 24.94 \\
\hline 17 & Market value & Myrtus communis, CLT 7, 50-70 cm, fully textured & Number & 4 & 3.31 & 13.24 \\
\hline 18 & Market value & Pistacia terebinthus, CLT 7, 50-70 cm, fully textured & Number & 3 & 3.88 & 11.64 \\
\hline 19 & Market value & Rhaphiolepis indica, CLT $5,40-50 \mathrm{~cm}$, fully textured & Number & 4 & 4.91 & 19.63 \\
\hline 20 & Market value & Rosmarinus officinalis, CLT 3, 25-30 cm, fully textured & Number & 12 & 1.37 & 16.43 \\
\hline 21 & Market value & Salvia officinalis 'Tricolor', CLT 2, 20-25 cm, fully textured & Number & 10 & 1.26 & 12.55 \\
\hline 22 & Market value & Salvia officinalis, CLT $2,20-25 \mathrm{~cm}$, fully textured & Number & 21 & 1.20 & 25.16 \\
\hline 23 & Market value & Santolina chamecyparissus, CLT 3, 25-30 cm, fully textured & Number & 16 & 1.31 & 21.00 \\
\hline 24 & Market value & Santolina rosmarinifolia, CLT $2,20-25 \mathrm{~cm}$, fully textured & Number & 40 & 1.26 & 50.21 \\
\hline 25 & Market value & Spartium junceum, CLT $4,30-40 \mathrm{~cm}$, fully textured & Number & 8 & 2.45 & 19.63 \\
\hline 26 & Market value & Tamarix gallica, CLT 9, $60-80 \mathrm{~cm}$, fully textured & Number & 8 & 4.68 & 37.43 \\
\hline 27 & Market value & Teucrium fruticans, CLT $5,40-50 \mathrm{~cm}$, fully textured & Number & 12 & 2.62 & 31.50 \\
\hline 28 & Market value & Thymus vulgaris, CLT 2, 20-25 cm, fully textured & Number & 12 & 1.31 & 15.75 \\
\hline 29 & Market value & Vitex agnus-castus, CLT 7, $50-70 \mathrm{~cm}$, fully textured & Number & 2 & 3.99 & 7.99 \\
\hline 30 & Market value & Carboprotus edulis, in viols. & Number & 1,060 & 0.14 & 151.21 \\
\hline 31 & Market value & Lampranthus roseus, in viols. & Number & 8,121 & 0.14 & $1,158.46$ \\
\hline 32 & Market value & Lampranthus spectabilis, in viols. & Number & 207 & 0.14 & 29.53 \\
\hline 33 & Market value & Lonicera etrusca, CLT 2, 20-30 cm, fully textured & Number & 24 & 2.05 & 49.30 \\
\hline 34 & Market value & Lotus berthelotii, in viols. & Number & 59 & 0.14 & 8.42 \\
\hline 35 & Market value & Portulaca grandiflora, in viols. & Number & 5,586 & 0.14 & 796.84 \\
\hline 36 & Market value & Sedum mexicanum 'Aureum', in viols. & Number & 558 & 0.14 & 79.60 \\
\hline 37 & Market value & Sedum sediforme, in viols. & Number & 1,936 & 0.14 & 276.17 \\
\hline 38 & Market value & Peat (double harvested, sieved, disinfected) $(3 \mathrm{~cm})$ & $\mathrm{m}^{3}$ & 49.07 & 18.36 & 901.02 \\
\hline \multicolumn{3}{|r|}{ Prepared according to 2015 market values } & \multicolumn{3}{|c|}{ TOTAL } & $€ 4,652.52$ \\
\hline
\end{tabular}


Table 3. Annual maintenance needs for existing and proposed projects.

\begin{tabular}{|c|c|c|}
\hline Annual maintenance & Existing project & Proposed project \\
\hline \multirow{4}{*}{ Irrigation } & Once a week/April-May & Once every 3 weeks/April-May \\
\hline & Three times a week/May-September & Once every 2 weeks/May-September \\
\hline & Once a week/September-November & Once every 2 weeks/ September-November \\
\hline & Once every 3 weeks/November-April & If needed November-April \\
\hline \multirow{3}{*}{ Moving Grass } & Once every 10 days/May-September & \\
\hline & Once every 20 days/September-December and in April & \\
\hline & Depends on the need during other months & \\
\hline \multirow{3}{*}{ Moving weed } & Once every 10 days/May-September & Once every 3 weeks/May-September \\
\hline & Once every 20 days/September-November & Once every 6 weeks/September-November \\
\hline & Depends on the need during other months & Depends on the need during other months \\
\hline \multirow{3}{*}{ Pruning } & Twice a year for trees & Once or twice a year for trees \\
\hline & Pruning for shape for appropriate trees and shrubs & $\begin{array}{l}\text { Depends on the need for trees, shrubs, and } \\
\text { perennials }\end{array}$ \\
\hline & Once every two months for shrubs and perennials & \\
\hline Fertilization & 3 times a year & 2 times a year \\
\hline Disinfection & 4 times a year & 2 times a year \\
\hline
\end{tabular}

Table 4. Proposed project additional application supply summary.

\begin{tabular}{|c|c|c|c|c|c|c|}
\hline Item No. & Pose number & Explanation & Unit & Total & Price $(€)$ & Total price $(€)$ \\
\hline 1 & Market value & Quartz sand & $\mathrm{m}^{3}$ & 1.27 & 18.26 & 23.19 \\
\hline 2 & Market value & Tree chips with natural colour $8-12 \mathrm{~mm}$ & $\mathrm{~m}^{3}$ & 6.23 & 67.33 & 419.47 \\
\hline 3 & Market value & Red volcanic tuff $8-12 \mathrm{~mm}$ & $\mathrm{~m}^{3}$ & 0.94 & 71.90 & 67.58 \\
\hline \multicolumn{2}{|c|}{ Prepared according to 2015 market values } & \multicolumn{3}{c|}{ TOTAL } & $€ 510.24$ \\
\hline
\end{tabular}

a healthy appearance. The existing park employs two inappropriate grass species - Festuca rubra rubra and Lolium perenne - which are cool-climate grasses (C3) that require more water and enrichment. The proposed park utilizes ground-cover species as an alternative, which require only limited weed control and irrigation. Furthermore, these plants provide a more colorful and aesthetic appearance.

Xeriscaping is of great interest to landscape architecture studies focused on sustainability [43]. Stringer et. al. [44] points out that a holistic approach that combines xeriscaping principles with rain water harvesting on even a residential scale will facilitate water conservation, money savings, decrease storm water pollution, and increase property values. Bayramoğlu and Demirel [45] add to these advantages a decrease of time spent on fertilization and other maintenance work, and of energy consumption and the expansion of natural habitats for plants and animals.

Mayer et. al. [46] show that it is possible to reduce outdoor water use by $15-65 \%$ or more by specific measures such as xeriscaping or soil moisture sensors. Chui [47] measured public perception of visual attractiveness versus water conservation on examples of front yard landscapes, and found that most people who answered the questionnaire considered xeriscaping to be less attractive than lawns, and the sensor system expensive to establish. That study suggests that though people are aware of climate change and the decrease of water resources, it is not yet reflected in their actions. Nonetheless, these results show the significance of studies that calculate the feasibility of water-conserving landscape designs. This study has shown that the sensor system becomes reasonable for a large-scale area such as a public park, which creates a more favorable ratio in cost outlay.

This study's results are supported by those of Wilkinson [48], who analyzed the feasibility of xeriscaping the parks of Pomona, California, USA. Though this showed that xeriscaping all of them at once would be cost prohibitive, the Pomona Parks Department is gradually and methodically replacing plants of exorbitant water need with native and water-conserving 
species of grass and succulents. New efficient irrigation systems are projected to save the city $30-50 \%$ of current water usage. A $30 \%$ reduction alone would save nearly \$2 million annually.

\section{Conclusions}

This comparative analysis of landscaping methods for the Konyaaltı District of Antalya has demonstrated qualitatively and quantitatively the necessity and applicability of the xeriscape in Mediterranean conditions. It also has shown that determining the natural structural properties of the region in which a design area is located, and planning based on these characteristics, are critical for resource sustainability. This study is one of the first that models how xeriscaping works on a large scale in public spaces in a regional and national park system, and how such a public space can improve sustainability and increase savings within a national system.

It is obvious that from residential gardens to urban public spaces, xeriscaping is more beneficial than conventional methods in economic and ecological terms. To encourage water savings, it is recommended that public institutions in Turkey provide incentive premiums to encourage xeriscaped designs and to curtail grass use, make automatic irrigation systems compulsory, restrict the importation of introduced species, and apply sanctions on those who ignore these stipulations. It also suggests that to encourage xeriscape practices, effective use of media, distribution of educational brochures, and providing training will contribute to public awareness. It should always be remembered that water is a scarce and valuable resource that has a right to life.

\section{References}

1. ÇORBACI Ö.L., ÖZYAVUZ M., ve YAZGAN M.E. Intelligent use of water in landscape architecture Xeriscape, Journal of Agricultural Sciences Research, 4 (1), 25, 2011.

2. STROUD H.B., KILMER M.K. Developing a Sustainable Water Supply in the American West: The Case of Rio Rancho, New Mexico. Suburban Sustainability: 4 (1), Article 1. 2016. [Available at: http://scholarcommons.usf.edu/subsust/ vol4/iss1/1].

3. CHOIŃSKI A., PTAK M., ŁAWNICZAK A., E. Changes in Water Resources of Polish Lakes as Influenced by Natural and Anthropogenic Factors. Polish Journal of Environmental Studies. 25 (5), 1883, 2016.

4. BARRACLOUGH C., LUCEY P., Water-Sensitive Urban Design Aqua-Tex Scientific Consulting Ltd., Victoria, B.C., Canada Mortgage and Housing Corporation, 2010.

5. ABD EL AZIZ N.A. Water Sensitive Landscape Case Study: Public Open Green Spaces In Naser City, Egypt. Journal of Landscape Ecology, 9 (3), 2016.

6. CABRERA R.I., WAGNER K.L., WHERLEY B. Texas Water Resources Institute, Texas Water Journal, 4 (2), 14, 2013.

7. DUKES M.D. Water conservation potential of landscape irrigation smart controllers. Transactions of the American
Society of Agricultural and Biological Engineers 55 (2), 563, 2012.

8. DAVIS S.L., DUKES M.D. Landscape irrigation with evapotranspiration controllers in a humid climate. Transactions of the American Society of Agricultural and Biological Engineers 55 (2), 571, 2012.

9. KNOX G.W. Landscape design for water conservation. University of Florida IFAS Extension, 3, 2005.

10. AKLANOĞLU F. Climate change impacts on landscape design and practices. International Conference on Climate Change and Environmental Effects (UKIDEK), 18-20 October, Konya, 2007.

11. BARIŞ M.E. Who and how can we rediscover our cities that are decorated with yellow? Available at: http:// www.peyzajmimoda.org.tr/genel/bizden_detay. php?kod=1173\&tipi $=2 \&$ sube $=0,2007$.

12. ERTOP G. Global warming and Xeriscape planning, Ankara University, Thesis of Master, Ankara, 164, 2009.

13. NOVOTNY V. Water - energy nexus: retro fitting urban areas to achieve zero pollution. Build Res Inform, 41, 589, 2013.

14. POZO L., LEBRATOR J., GARVIL D., JIGENA B., MUÑOZ J.J., Naturalization: A New Concept Developed And Carried Out In The Subject "Environmental Technology" Of Degree In Industrial Engineering, Proceedings of INTED2016 Conference $7^{\text {th }}-9^{\text {th }}$ March, Valencia, Spain, 7891, 2016.

15. BECK T., FRANKLIN C., Principles of Ecological Landscape Design. Washington D.C.: Island Press., 2013

16. RAYNO V. The Water Efficient Landscape a first guide for designing water-wise gardens in the piedmont region of North Carolina, 2016. Available at: http://stud.epsilon.slu. se

17. WESCOAT J.L. The 'duties of water' with respect to planting: toward an ethics of irrigated landscapes. Journal of Landscape Architecture, 6, 2013.

18. WADE G.L., WEATHERLY E.N.JR. Xeriscaping saves water but does it save money. Proceedings of the 1991 Georgia Water Resources Conference, 103, Athens, Georgia, 1991.

19. SANTO J.M. Local government's role in water efficient landscaping Atlanta regional commission policy on waterefficient landscaping, 100, Atlanta, 1991.

20. BAYKAN N.M, BİRIŞÇİ T. Xeriscape with the sustainable landscape approach; case study of Ege University, Faculty of Agriculture garden. V. Ornamental Plants Congress, 0609 May 2013, 523, Yalova, 2013.

21. ŞAHIN N. Effective and rational use of water in xeriscape landscaping. M.Sc. Thesis, Muğla Sttkı Koçman University, Muğla, 65, 2013.

22. WADE G.L., MIDCAP J.T., CODER K.D., LANDRY G., TYSON A.W., JR. N.W. Xeriscape A Guide to developing a water-wise landscape. The University of Georgia College of Agricultural and Environmental Sciences, 40, 2007.

23. WELSH D.F. Xeriscape North Carolina. National Zeriscape Council, USA, 28, 2000.

24. TANER T.M. Effective use of water in landscaping, xeriscape. Master's Thesis, Ege University, İzmir, 56, 2010.

25. ÇAKIROĞLU G. Examination of current applications for water saving in landscape design; case study of Istanbul. İstanbul University, Thesis of Master, İstanbul, 174, 2011.

26. KEANE T. Water wise landscaping guide for water management planning. Utah State University Extension, 96, 1995.

27. SHARIFI A., YAMAGATA Y., Principles and criteria for assessing urban energy resilience: A literature review. Re- 
newable and Sustainable Energy Reviews, 60, 1654, 2016.

28. NOLON J. R., Enhancing the Urban Environment Through Green Infrastructure. 46 Envtl. L. Rep. 10071, 2016. Available at: http://digitalcommons.pace.edu/lawfaculty/1011/

29. U.S. EPA, How To Conserve Water and Use It Effectively, 2011, Available at: http://water.epa. gov/polwaste/nps/ chap3.cfm

30. KONYAALTI DISTRICT GOVERNORSHIP, 2016. Available at: http://www.konyaalti.gov.tr/

31. TÜİK (TURKISH STATISTICAL INSTITUTION), According to the adrese based population registration system, provincial people, metropolitan municipal population, and neighborhood population statistics, 2016. Available at: http://www.tuik.gov.tr/.

32. KONYAALTI MUNICIPALITY, Map showing the final limits of the province, Directorate of Estate and Expropriation, 2015.

33. MTA, $1 \backslash 100.000$ Scaled L11 sheet, General Directorate of Geological Survey, Mineral Research and Exploration, 1997.

34. KHGM (GENERAL DIRECTORATE OF VILLAGE SERVICES), Antalya Province Land Ownership. General Directorate of Village Services, Directorate of Survey and Project Department, Ankara, 109, 1993.

35. KHGM (GENERAL DIRECTORATE OF VILLAGE SERVICES), Soil Map. 1993a.

36. MGM (METEOROLOGY GENERAL DIRECTORATE), Antalya Province (Antalya Meteorology $4^{\text {th }}$ Regional Directorate and Antalya Airport Climate Station) climate data. Antalya, 2015.

37. KONYAALTI MUNICIPALITY, Data related to the park in the county, Parks and Gardens Directorate, 2015a.

38. ÇETIN N. Examination of the applicability of xeriscape in Mediterranean conditions. Akdeniz University, Thesis of Master, Antalya, 134, 2016.

39. WILSON C., FEUCHT J.R., Xeriscaping: creative landscaping. Colorado State University Extension, Colorado, 3, 2007.
40. ATIKK M., KARAGÜZEL O. Water saving possibilities in landscape architecture applications and priority of use of natural species as ornamental plants. Journal of Voice of Agriculture, TMMOB Chamber of Agricultural Engineers Antalya Branch, 15, 9, 2007.

41. MANSUROĞLU S., KINIKLI P., ve ERDOĞAN R. Xeriscape designs Applicability in Antalya. 1st National Drought and Desertification Symposium Book. 880, Konya, 2010.

42. KUMARASAMY M.V., DUBE V.N., Study on Recycling Urban Wastewater for Non-Potable Uses for Water Conservation, Polish Journal of Environmental Studies. 25 (1), 167, 2016.

43. BRITTENUM J.B., The Three P's: Plants, Planting Design and the Professional, Landscape Research Record. 2, 2014.

44. STRINGER A., VOGEL J., LAY J., NASH K., Design of Rainwater Harvesting Systems in Oklahoma, 2017. Available at: http://pods.dasnr.okstate.edu/docushare/dsweb/ Get/Document-8238/BAE-1757web.pdf

45. BAYRAMOĞLU E., DEMIREL Ö., Xerophytic Landscape, Environment and Ecology at the Beginning of $21^{\text {st }}$ Century, St. Kliment Ohridski University Press, ISBN 978954-07-3999-1, Sofia, 2015.

46. MAYER P., LANDER P., GLENN D.T. Outdoor Water Efficiency Offers Large Potential Savings, But Research on Effectiveness Remains Scarce ENVS Faculty Publications, 2015. Available at: http://digitalcommons.usu.edu/envs facpub/1000/

47. CHUI S.C.K. Visual attractiveness versus water conservation in front yard preferences in the context of drought in Melbourne, Australia, Australasian Journal of Water Resources, 18 (1), 85, 2014. Available at: http://dx.doi. org/10.7158/W13-006.2014.18.1

48. WILKINSON A., Water Conservation in Pomona: Feasibility of Xeriscaping and Irrigation in Pomona's Parks. 2015. Available at: http://www.cpp.edu/ tgyoung/Pom_Parks/ Water_Conservation_in_Pomona.pdf 